\title{
Machine Learning Untuk Estimasi Posisi Objek Berbasis RSS Fingerprint Menggunakan IEEE 802.11g Pada Lantai 3 Gedung JTETI UGM
}

\author{
${ }^{1}$ Chairani, ${ }^{2}$ Widyawan, ${ }^{3}$ Sri Suning Kusumawardani \\ ${ }^{1}$ Jurusan Teknik Informatika, IBI Darmajaya \\ ${ }^{2,3}$ Jurusan Teknik Elektro dan Teknologi Informasi Universitas Gadjah Mada \\ ${ }^{1}$ Jl. A. Pagar Alam, No. 93, Bandar Lampung, Indonesia \\ ${ }^{2,3} \mathrm{Jln}$. Grafika 2 Yogyakarta 55281 Indonesia \\ chairani.fauzi.fathir@gmail.com, widyawan@ugm.ac.id, suning@mti.ugm.ac.id
}

\begin{abstract}
Abstrak - Penelitian ini membahas tentang estimasi posisi (localization) objek dalam gedung menggunakan jaringan wireless atau IEEE 802.11g dengan pendekatan Machine Learning. Metode pada pengukuran RSS menggunakan RSS-based fingerprint. Algoritma Machine Learning yang digunakan dalam memperkirakan lokasi dari pengukuran RSS-based menggunakan Naive Bayes. Localization dilakukan pada lantai 3 gedung Jurusan Teknik Elektro dan Teknologi Informasi (JTETI) dengan luas 1969,68 $\mathrm{m}^{2}$ dan memiliki 5 buah titik penempatan access point (AP). Untuk membentuk peta fingerprint digunakan dimensi $1 \mathrm{~m} \mathrm{x} 1 \mathrm{~m}$ sehingga terbentuk grid sebanyak 1893 buah. Dengan menggunakan software Net Surveyor terkumpul data kekuatan sinyal yang diterima (RSS) dari jaringan wireless ke perangkat penerima (laptop) sebanyak 86.980 record. Hasil nilai rata-rata error jarak estimasi untuk localization seluruh ruangan di lantai 3 dengan menggunakan algoritma Naive Bayes pada fase offline tahap learning adalah 6,29 meter. Untuk fase online dan tahap post learning diperoleh rata-rata error jarak estimasi sebesar 7,82 meter.
\end{abstract}

Kata kunci - Localization dalam gedung, IEEE 802.11g, Received Signal Strength (RSS), Fingerprint, Naive Bayes

Abstract - This research discuss about object position estimation (localization) inside the building using wireless network or IEEE 802.11g with machine learning approach. Measurement method of RSS using RSS-based fingerprint. Machine learning algorithm used to estimate the location of measuring RSS-based with Naive Bayes.

The localozation conducted in third floor at Electronic Engineering and Information Technology Departement (JTETI) with 1969,68 $\mathrm{m} 2$ area and 5 point of access point placement. To build fingerprint map, we use $1 \mathrm{~m}$ x $1 \mathrm{~m}$ dimension thus formed 1983 grids. Using Net Surveyor software, received signal strength from wireless to receiver device gathered 86,980 record.

Mean distance estimation error value for the localization for whole room at third floor using Naïve Bayes algorthim in offline phase of learning stage is 6.29 meter. From online phase of learning stage resulting mean distance error 7.82 meter.

Keyword - Indoor Localization, IEEE 802.11g, Received Signal Strength (RSS), Fingerprint, Naive Bayes

\section{PENDAHULUAN}

Sistem penentuan posisi (localization) adalah teknologi utama untuk membangun ruang komputasi pervasif yang cerdas [1]. Localization merupakan salah satu bidang yang masuk kedalam ruang lingkup klasifikasi. Klasifikasi merupakan salah satu masalah yang dapat ditangani dengan menggunakan metode machine learning. Keunggulan dari penggunaan metode machine learning adalah karena kesederhanaannya dalam melakukan proses pembelajaran [12].

Localization digunakan untuk memprediksi lokasi dari perangkat mobile berdasarkan nilai-nilai data yang terukur. Lokasi dapat diwakili oleh (x, y) untuk bentuk dua dimensi, dimana $\mathrm{x}$ dan $\mathrm{y}$ merupakan koresponden masing-masing nilai koordinat $\mathrm{x}$ dan $\mathrm{y}$.
Sistem localization secara umum bertujuan untuk memperkirakan lokasi perangkat mobile berdasarkan nilai-nilai data terukur yang dikumpulkan dalam sebuah vektor yang diterima oleh perangkat mobile [11].

Ada beberapa teknologi yang dapat digunakan dalam membangun sistem localization, baik di luar gedung (outdoor) maupun di dalam gedung (indoor). Keberhasilan localization di luar gedung dan aplikasi berbasis Global Positioning System (GPS) menyediakan ruang untuk penelitian dan pengembangan sistem penentuan posisi dalam ruangan [14]. Keuntungan utama dari sistem GPS bisa mendapatkan posisi melalui sinyal dari satelit dan memiliki cara kerja dimana penerima harus berada pada posisi line of sight. Hal tersebut menjadikan sistem GPS tidak dapat digunakan secara efektif di 
dalam gedung karena penerimaan sinyal yang lemah [14]. GPS cocok digunakan pada area luar gedung atau lingkungan outdoor dengan tingkat kesalahan 5 meter sampai dengan 10 meter [13]. Teknologi lainnya adalah Cellphone. Cellphone cocok untuk lingkungan outdoor dengan prinsip telephone trunk yang memiliki akurasi 50 meter dengan biaya yang moderate. Namun, akurasi dari sistem posisi berbasis GSM dalam ruangan sangat dibatasi oleh ukuran sel atau CELL-ID [13]. GPS dan Cellphone (GSM) memiliki keterbatasan dalam efektivitas sistem untuk lingkungan dalam ruangan yang disebabkan oleh multipath dan pelemahan sinyal [15].

Teknologi yang dapat digunakan untuk membangun sistem posisi dalam gedung antara lain Bluetooth, RFID, Zigbee, UWB dan IEEE 802.11. Bluetooth memiliki tingkat akurasi 2 meter untuk localization dalam gedung dan memiliki skalabilitas atau jarak dimensi penempatan nodes setiap 2 meter sampai dengan 15 meter agar memperoleh tingkat akurasi maksimum. RFID memiliki akurasi kurang dari 2 meter dengan skalabilitas pemasangan nodes secara densely. UWB merupakan teknologi yang memiliki tingkat biaya yang tinggi dengan tingkat akurasi 15 sentimeter, dengan skalabilitas penempatan sensor antara 2 sampai 4 buah sensor per cell (100-1000m). WLAN atau IEEE 802.11 memiliki tingkat akurasi antara 3 meter sampai dengan 5 meter, serta memiliki skalabilitas yang baik untuk 2D/3D [10].

Peningkatan penyebaran IEEE $802.11 \mathrm{~b} / \mathrm{g}$ atau WLAN oleh banyak individu dan organisasi baik dalam rumah, kantor, bangunan, dan kampus telah menjadikan popularitas WLAN begitu tinggi. Infrastruktur WLAN juga dapat diterapkan untuk memberikan layanan lokasi dalam ruangan tanpa menggunakan peralatan tambahan [14]. Hal ini dapat terlihat dengan adanya berbagai area aplikasi yang dibutuhkan oleh pengguna secara luas dengan menggunakan teknologi WLAN (misalnya area aplikasi konsumen, medis, industri, keselamatan umum, logistik, dan sistem transportasi bersama dengan aplikasi lainnya).

Localization dalam gedung dengan penggunaan teknologi IEEE 802.11 atau WLAN menggunakan teknik fingerprint, hal ini dikarenakan ketika hubungan analitis antara pengukuran RSS dan jarak tidak mudah dibentuk karena multipath dan interferensi [2]. Keunggulan jenis sistem posisi berbasis fingerprint antara lain tidak memerlukan hardware khusus selain antarmuka jaringan yang umum seperti nirkabel dengan kemampuan pengukuran RSS, oleh karena itu relatif mudah diimplementasikan dibandingkan dengan teknik lain. Keutungan lainnya adalah lokasi fingerprint juga bisa diimplementasikan sebagai positioning system berbasis software yang dapat mengurangi kompleksitas dan biaya. Setiap infrastruktur WLAN yang ada dapat digunakan kembali untuk positioning system. Sistem penentuan posisi tersebut dipandang sebagai solusi yang paling efektif dan layak untuk lingkungan indoor [8][9].

Karena teknologi GPS kurang efektif untuk digunakan pada sistem localization dalam gedung, serta penggunaan teknologi RFID, Zigbee, serta $U W B$ untuk sistem localization memerlukan biaya yang besar dalam membangun infrastruktur untuk localization dalam gedung, maka dibuatlah sistem localization dengan menggunakan WLAN atau IEEE 802.11 untuk mengestimasi lokasi dengan menggunakan pendekatan machine learning.

WLAN digunakan karena memiliki beberapa keunggulan antara lain kekuatan sinyal (signal strength) yang dapat menembus dinding sehingga sistem dapat digunakan dilebih dari satu ruangan, sangat mudah dan cepat untuk diinstal, memiliki tingkat biaya yang lebih rendah daripada teknologi lainnya, dapat digunakan di tempat-tempat yang bersifat indoor maupun outdoor, memiliki sistem yang memungkinkan jumlah pengguna yang tinggi [7], memiliki daya jangkau sinyal yang cukup besar untuk area lokal terhadap orang yang menggunakan teknologi wireless dalam kehidupan sehari-hari terutama di kantor, serta teknologi yang bersifat off the shelf. Dengan biaya yang rendah serta sudah adanya dukungan infrastruktur dalam gedung, teknologi WLAN dapat dimanfaatkan dalam membangun sistem localization dalam gedung untuk mengetahui tingkat akurasi dari estimasi posisi dalam gedung

\section{METODOLOGI PENELITIAN}

\section{A. Metode Kajian}

Pada indoor localization tahapan-tahapan dalam metode machine learning terdiri dari (Gambar 1) [5]:

1. Tahap Pre-Learning

a. Tahap identifikasi data dan knowledge source merupakan tahapan spesifikasi parameter sistem pengukuran nilai $R S S$ dari multiple access point yang ada di gedung Teknik Elektro. Proses pengukuran dilakukan dengan mengabaikan adanya efek multipath dan propagasi.

b. Tahap acquire data dan knowledge merupakan tahapan penetapan lokasi fingerprint yang akan diukur dalam gedung dengan menetapkan grid atau titik-titik pengukuran (predefined) dalam bentuk koordinat $(\mathrm{x}, \mathrm{y})$.

c. Tahap preprocessing

Merupakan tahap pemrosesan data dari langkah (b). Preprocessing dilakukan dengan menghilangkan RSS WLAN dan atribute access pointt yang berada diluar area Teknik Elektro dan Teknologi Informasi (JTETI) UGM Lantai 3 meskipun sinyal tersebut tertangkap. Pada tahap 
prepocessing akan dibuat juga database fingerprint RSS WLAN. Database fingerprint ini kemudian diolah untuk menghasilkan Visualisasi peta fingerprint.

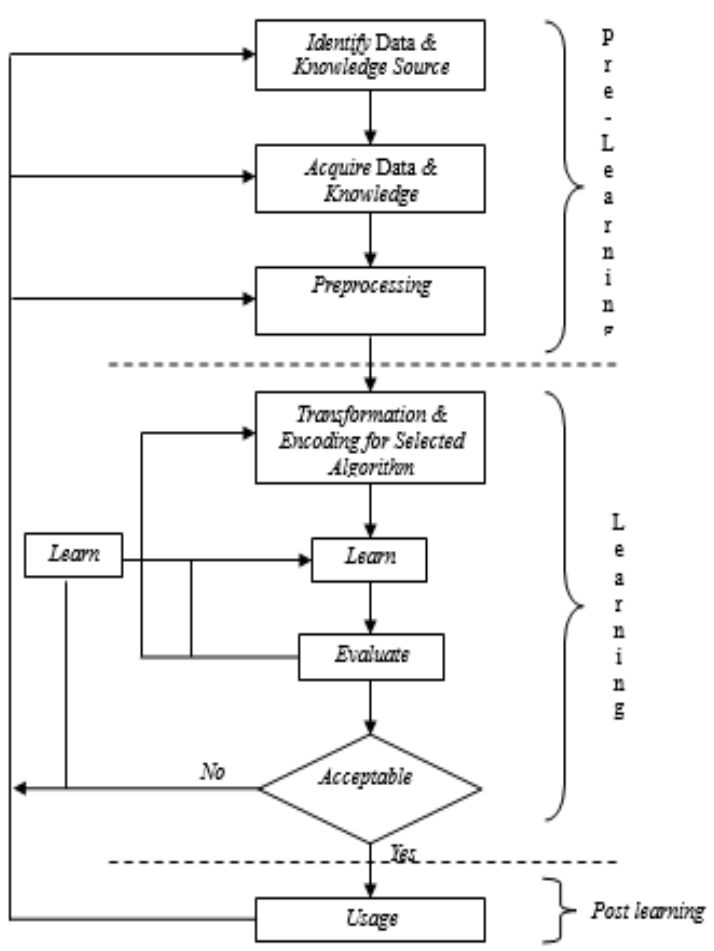

Gambar 1. Metode Machine Learning

2. Tahap Learning

Merupakan tahapan proses pembelajaran pengenalan posisi yang dilakukan terhadap database fingerprint dengan menggunakan algoritma Naive Bayes.

\section{B. Teknik Localization}

Teknik localization (Gambar 2) terdiri dari dua buah fase, yaitu fase offline dan fase online. Fase offline merupakan proses dilakukannya pengukuran Received Signal Strength (RSS) dari multiple access point (AP) yang berfungsi untuk membangun database yang disebut sebagai peta radio untuk lingkungan target (database fingerprint).

Fase online dilakukan untuk menghitung lokasi dengan cara membandingkan RSS diukur dengan RSS yang disimpan dalam database. Pada tahap online dikenal dengan teknik posisi karena pada tahap ini dilakukan pengukuran $R S S$ secara real time oleh penerima kemudian menghitung koordinat lokasi yang diperkirakan berdasarkan dabatase peta radio dengan menggunakan algoritma posisi.

\section{Metode Penyimpulan Lokasi Yang Telah Diindentifikasi}

$R S S$ adalah kekuatan sinyal yang diterima oleh penerima jarak jauh dari pemancar. Secara umum, $R S S$ menurun secara proporsional dengan jarak. Jika hubungan jarak kekekuatan sinyal diketahui, baik analitis atau empiris, jarak antara dua perangkat dapat dihitung. Ada beberapa keuntungan menggunakan RSS untuk localization dalam gedung. Pertama, dapat diimplementasikan dalam sistem komunikasi nirkabel dengan tidak ada perubahan pada perangkat keras atau sedikit perubahan pada perangkat keras. Kedua, tidak memerlukan sinkronisasi antara pemancar dan penerima.Keuntungan ini merupakan faktor utama yang berkontribusi terhadap keterjangkauan yang lebih besar dan penggunaan RSS untuk localization dalam gedung. Kekurangan utama adalah bahwa pembacaan RSS dapat menunjukkan variasi besar karena interferensi dan multipath pada saluran radio [13]. Gambar 2 merupakan arsitektur sistem localization dalam gedung.

Pengukuran nilai RSS dari multiple access point yang ada di gedung Teknik Elektro dan Teknologi Informasi (JTETI) UGM dilakukan dengan mengabaikan adanya efek multipath dan propagasi, dengan menetapkan lokasi fingerprint yang akan diukur dalam gedung berupa penetapan grid atau titik-titik pengukuran (predefined) dalam bentuk koordinat $(\mathrm{x}, \mathrm{y})$. Penetapan grid menggunakan ukuran $1 \mathrm{~m} \mathrm{x} 1 \mathrm{~m}$. Tahap pengukuran RSS dilakukan dengan menggunakan software NetSurveyor (Gambar 3). Pengukuran dilakukan pada titik tengah masingmasing grid. Preprosesing data dilakukan dengan memilih atribute access point dan nilai RSS yang sesuai dengan penggunaan AP.

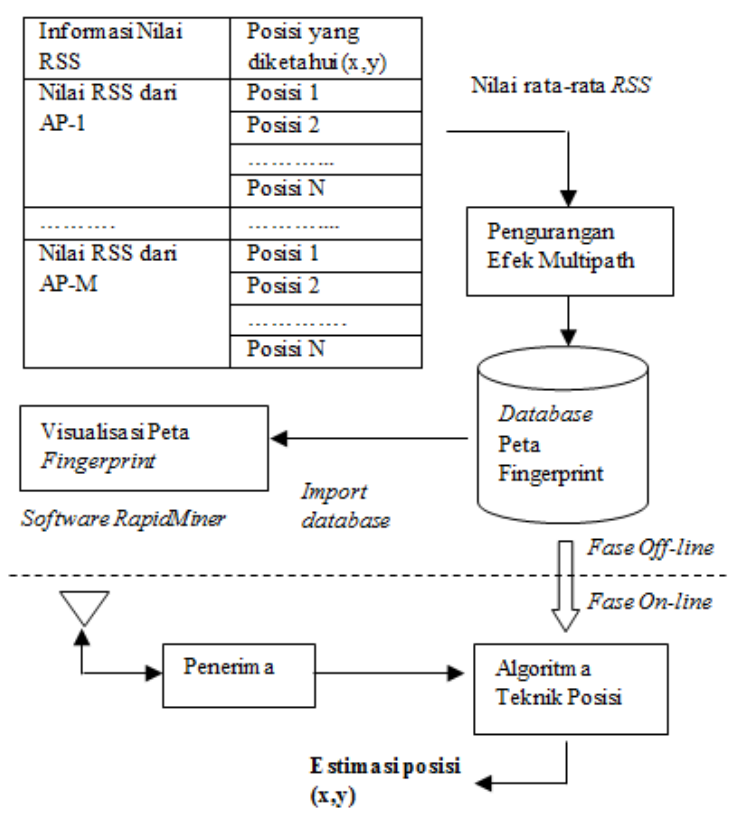

Gambar 3. Arsitektur sistem localization

Hasil seluruh rata-rata dari masing-masing grid yang telah ditetapkan nilai koordinatnya kemudian disimpan dalam database fingerprint. Database fingerprint diimpor kedalam program RapidMiner dengan menetapkan atribute class yang berisi titik koordinat $\mathrm{x}$ dan y. Database fingerprint ini kemudian diolah untuk menghasilkan visualisasi peta 


\section{fingerprint.}

\section{Pengolahan Data Terukur}

Fingerprinting adalah metode untuk pemetaan data yang terukur (misalnya $R S S$ ) ke dalam titik-grid yang meliputi seluruh cakupan wilayah localization. Lokasi diperkirakan dari perbandingan antara pengukuran $R S S$ real-time dan $R S S$ yang sebelumnya disimpan dalam fingerprint. Fingerprinting sering digunakan untuk localization berbasis dalam gedung atau dalam ruangan, terutama ketika hubungan analitis antara pengukuran $R S S$ dan jarak tidak mudah dibentuk karena multipath dan interferensi [2].

Model sistem posisi dalam ruangan dan lokasi fingerprints dapat dinyatakan sebagai sebuah vektor $F=\left(\rho_{1}, \rho_{2}, \rho_{3}, \ldots, \rho_{n}\right)$ elemen rata-rata $R S S$. Untuk satu lokasi area fingerprint maka fingerprint lokasi adalah $\left\{F_{1}, F_{2}, F_{3}, \ldots, F_{n}\right\}$. Pengukuran $R S S$ fingerprint selama fase off-line dinotasikan sebagai $\mathrm{S}$ yang dapat dijadikan sebagai mean atau rata-rata sampel RSS yang diperoleh dari pengukuran RSS berdasarkan durasi waktu yang tidak terlalu lama [8][9].

Sistem posisi dalam ruangan menganggap nilai rata-rata $R S S$ dari N APs sebagai lokasi fingerprint $\left[F_{i}=\left(\rho_{1}^{i}, \rho_{2}^{i}, \rho_{3}^{i}, \ldots, \rho_{N}^{i}\right)\right]$ sampel dari vektor $R S S$ adalah $S=s_{1}, s_{2}, s_{3}, \ldots, s_{n}$ dan setiap fingerprint lokasi $i$ didalam database dapat dinotasikan sebagai L. Setiap fingerprint merupakan pemetaan one-to-one ke sebuah set posisi $\left\{L_{1}, L_{2}, L_{3}, \ldots, L_{n}\right\}$. Informasi lokasi $L$ sebagai sistem koordinat dua atau tiga dimensi dan dapat digunakan orientasi pada mobile station's misal dapat menghadap utara, selatan, barat, atau timur [8][9]. Dalam penelitian ini, penulis menggunakan dua dimensi dalam sistem koordinat dan hanya menggunakan satu orientasi dalam melakukan koleksi fingerprint, yaitu dengan arah pengukuran menghadap utara.

Propagasi sinyal dalam ruangan sangatlah kompleks. Isu yang paling menantang dari WLAN Fingerprint adalah nilai $R S S$ WLAN yang tidak stabil tiap kali dilakukan pengukuran. Hal ini dikarenakan adanya efek multipath (yang disebabkan oleh refleksi, difraksi, dan difusi. Efek multipath dapat ditangani dengan merata-ratakan nilai $R S S$ [6]. Sehingga untuk mengurangi noise dari sebaran sinyal WLAN digunakan perhitungan rata-rata dari nilai $R S S$ yang telah diukur selama \pm 1 menit 56 detik dengan menggunakan persamaan (1) dan persamaan (2).

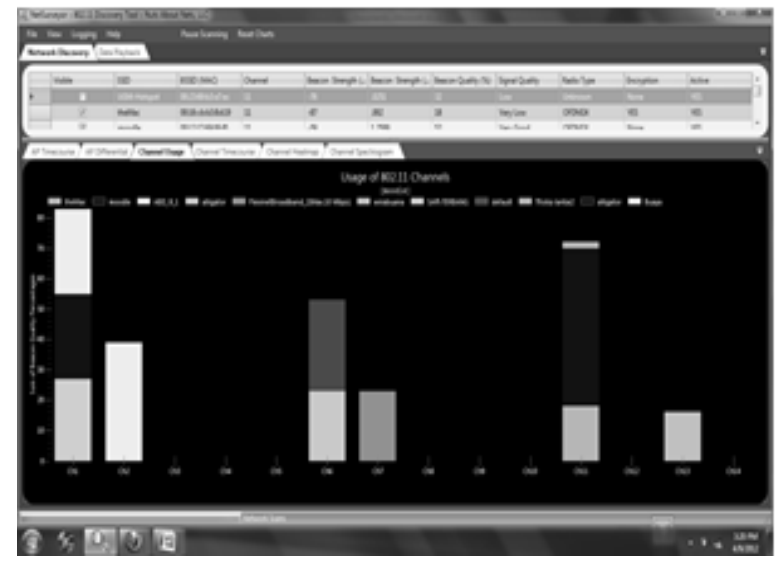

Gambar 4. Pengukuran RSS Menggunaan Software Net Surveyor

$$
\begin{aligned}
& \text { TA_RSS }{ }^{m}=A\left[y^{m}(n)\right] \\
& =\frac{1}{N} \sum_{n=0}^{n-1} y^{m}(n)
\end{aligned}
$$

Dengan y merupakan nilai $R S S$ diukur dari $\mathrm{m}$ di lokasi yang tetap, $\mathrm{m}$ adalah indeks dari $\mathrm{AP}, \mathrm{m}=0,1,2$, $3, \ldots, \mathrm{m}-1$. n merupakan indeks waktu diskrit, dan A merupakan proses rata-rata terhadap waktu yang indeksnya-n, dan $\mathrm{N}$ menunjukkan panjang dari urutan waktu.

Hasil seluruh rata-rata dari masing-masing grid yang telah ditetapkan nilai koordinatnya kemudian disimpan dalam database fingerprint. Database fingerprint diimpor kedalam program RapidMiner dengan menetapkan atribute class yang berisi titik koordinat $\mathrm{x}$ dan y. Database fingerprint ini kemudian diolah untuk menghasilkan visualisasi peta fingerprint.

\section{E. Algoritma Machine Learning Untuk Teknik Posisi}

\section{Algoritma Naive Bayes}

Naive Bayes Classifier merupakan algoritma klasifikasi yang berdasarkan pada teorema bayes. Algoritma posisi fingerprint menggunakan pendekatan probabilistik seperti maximum likehood (ML). ML diadopsi menjadi algoritma posisi, dengan penjelasan sebagai berikut: [3].

Perangkat mobile akan menerima sebuah set signature sinyal dari access point (AP), yaitu $\mathrm{An}=$ $\left\{A P_{1}, A P_{2}, A P_{3}, \ldots, A P_{n}\right\}$, dengan $\mathrm{AP}_{a}$ adalah $\mathrm{AP}(1 \leq$ $a \leq n)$ dan $n$ adalah nomor APs dalam gedung. $\mathrm{ss}_{\mathrm{a}}$ merupakan kekuatan sinyal yang diterima oleh perangkat penerima (laptop) dari $\operatorname{AP}_{a}(1 \leq a \leq n)$. Jika perangkat mobile tidak dapat menerima sinyal dari $\mathrm{AP}_{a}$ maka akan diberikan kekuatan sinyalnya menjadi -100 dbm. Nilai RSS yang diterima pada fase on-line oleh perangkat penerima dapat dituliskan sebagai sebuah vektor $\mathrm{S}=\left[\mathrm{ss}_{1}, \mathrm{ss}_{2}, \mathrm{ss}_{3}, \ldots, \mathrm{ss}_{\mathrm{n}}\right]^{\mathrm{T}} . R S S$ dari setiap referensi titik akan dimodelkan kedalam Gaussian Distribution (persamaan (5)), sehingga estimasi likelihood menjadi practicable. Total titik 
(points) direpresentasikan sebagai set $\mathrm{R}$ dan $|\mathrm{R}|=\mathrm{N}$. $\operatorname{RPx}=\left[r p_{i}^{x}, r p_{2}^{x}, r p_{3}^{x}, \ldots, r p_{n}^{x}\right]$ merupakan sebuah vektor $R S S$ yang diterima dari $\mathrm{n}$ APs pada referensi titik ke-x, dan $\Delta_{x}=\left[\Delta_{1}^{x}, \Delta_{2}^{x}, \Delta_{3}^{x}, \ldots, \Delta_{n}^{x}\right]$ sebagai vektor standar deviasi pada referensi titik x.

Dasar penentuan localization adalah mencari $\mathrm{P}$ probabilitas tertinggi $\mathrm{P}(\mathrm{x} \mid \mathrm{S})$ dimana $R S S$ diukur sebagai $S$, titik acuan $x$ dengan probability tertinggi $\mathrm{P}(\mathrm{x} \mid \mathrm{S})$ berarti bahwa kekuatan sinyal dari $\mathrm{x}$ adalah yang paling mirip dengan sinyal yang diukur dari perangkat mobile. Menurut aturan Bayes probabilitas dapat dihitung:

$$
P(x \mid S)=\frac{P(x \mid S) P(x)}{P(S)}=C x P(S \mid x)
$$

dengan $\mathrm{C}$ adalah skala konstan jika $\mathrm{x}$ mengikuti distribusi normal. Oleh karena itu, nilai $\mathrm{P}(\mathrm{x} \mid \mathrm{S})$ tergantung pada nilai $\mathrm{P}(\mathrm{S} \mid \mathrm{x})$. dengan demikian, titik $\mathrm{x}$ referensi dikatakan lokasi perangkat mobile jika probabilitas $\mathrm{P}(\mathrm{S} \mid \mathrm{x})$ adalah yang tertinggi.

Persamaan (4) digunakan untuk mencari perkiraan koordinat sebagai rata-rata semua lokasi dengan mengadopsi kemungkinan normalisasi sebagai bobot untuk memberikan hasil yang lebih akurat.

$$
x^{\prime}=\sum x=\frac{P(S \mid x)}{\sum_{x \in R} P(S \mid x)}
$$

Karena RSS diukur pada setiap titik acuan maka dapat dimodelkan sebagai distribution Gaussian, probabilitas $\mathrm{P}(\mathrm{S} \mid \mathrm{x})$ dapat dihitung sebagai.

$$
P(S \mid x)=\prod_{a}^{n} \frac{1}{\sqrt{2 \pi\left(\Delta_{a}^{x}\right)^{2}}} \exp \left\{\frac{-\left(s s_{a}-r p_{a}^{x}\right)^{2}}{2\left(\Delta_{a}^{x}\right)^{2}}\right\}
$$

\section{F. Perhitungan Nilai Akurasi Dari Estimasi}

Localization

Akurasi (location error) merupakan hal penting didalam sistem posisi. Biasanya, mean distance error digunakan sebagai penghitungan performance metric yang diperoleh dengan mencari rata-rata euclidean distance antara estimasi lokasi dan lokasi sebenarnya [10].

Untuk menghitung nilai akurasi (location error) dilakukan dengan cara menghitung error jarak dari perkiraan posisi $(\mathrm{x}, \mathrm{y})$ dan rata-rata error jarak pada proses pembelajaran dengan menggunakan persamaan (6) dan persamaan (7) yang diadopsi dari penghitungan jarak vektor. Standar deviasi digunakan untuk mengetahui rentang rata-rata nilai data error jarak terhadap nilai data error jarak pada persamaan (8) [4].

$$
\begin{aligned}
& \text { ErrorJarak }_{i}=\sqrt{\left(p_{x}-a_{x}\right)^{2}+\left(p_{y}-a_{y}\right)^{2}} \\
& \text { RataRataEr rorJarak }=\frac{1}{N} \sum_{x=1}^{N} \text { ErrorJarak }_{i}
\end{aligned}
$$

dengan $p$ adalah prediksi lokasi dan $a$ adalah lokasi aktual (lokasi target sebenarnya)

$$
\sigma_{x}=\frac{1}{N-1}\left\{\sum_{i=1}^{N} x_{i}^{2}-\frac{1}{N}\left[\sum_{i=1}^{n} x_{i}\right]^{2}\right\}
$$

$x_{i}$ merupakan error jarak estimasi (error jarak) yang terdiri dari $x_{1}, x_{2}, x_{3}, \ldots, x_{N}$ serta $\mathrm{N}$ adalah banyaknya jumlah data error jarak estimasi.

\section{G. Cross-Validation}

$K$-fold cross validation merupakan cara untuk menemukan parameter terbaik dari satu model dengan cara menguji besarnya error pada data test. Dalam $k$ fold cross validation datset $\mathrm{X}$ akan diambil secara random kedalam ukuran $\mathrm{K}$ bagian, $\mathrm{Xi}, \mathrm{i}=1, \ldots, \mathrm{K}$. Dengan menggunakan $k$-fold cross validation akan dilakukan percobaan sebanyak $\mathrm{k}$ buah. Tiap percobaan akan menggunakan satu buah data testing dan k-1 bagian menjadi data training, dan kemudian data testing tersebut akan ditukar dengan satu buah data training sehingga untuk tiap percobaan akan didapatkan data testing yang berbeda-beda [11].

\section{H. Pengukuran Performance Klasifikasi}

Ketika melakukan pengukuran performance klasifikasi terhadap masing-masing algoritma machine learning yang digunakan, ada beberapa ukuran dalam melihat performance klasifikasi tersebut, antara lain [5].

\section{Error}

Merupakan jumlah kesalahan yang diperoleh dari jumlah false positive ( $f p)$ dan false negative ( $f n$ ) yang dibagi terhadap total data positif (p) dan data negative $(\mathrm{n})$ atau error $=(f p+f n) / \mathrm{N}$

\section{Accuracy}

Accuracy menunjukkan kedekatan antara nilai prediksi dengan nilai akutual (real). Accuracy dihitung dengan persamaan $(t p+t n) / \mathrm{N}$, dengan tp sebagai true positive dan th adalah true negative.

True positive menyatakan jumlah sample positive yang memiliki prediction positive. False positive menyatakan jumlah sample positive yang memiliki prediction negative. True negative merupakan sample negative yang memiliki prediction negative, dan false positive merupakan sample negative yang memiliki prediction positive

\section{HASIL PENELITIAN}

\section{A. Fase Offline dan Tahap Learning}

Gedung JTETI lantai 3 memiliki luas bangunan $1969,68 \mathrm{~m}^{2}$. Terbentuk grid sebanyak 1893 buah dengan jumlah data 86.980 record. Gambar 5 sampai dengan Gambar 9 merupakan gambar visualisasi peta fingerprint pada seluruh lantai 3 gedung JTETI. 


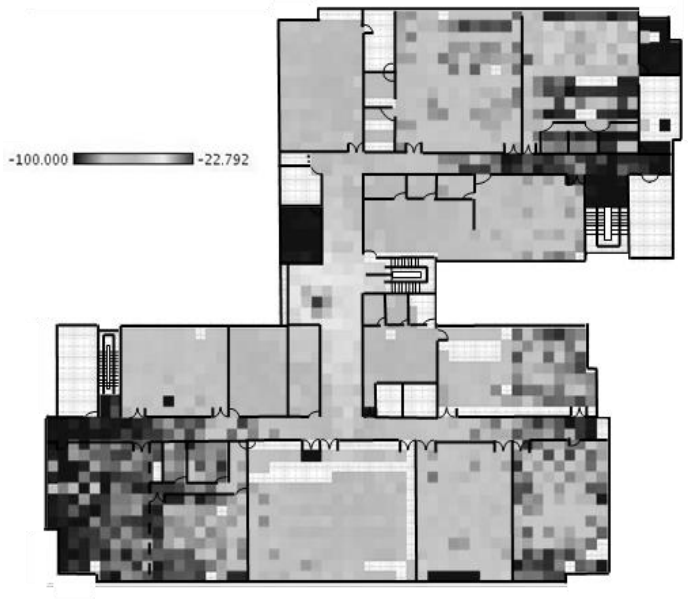

Gambar 5. Visualisasi peta fingerprint pada AP-1

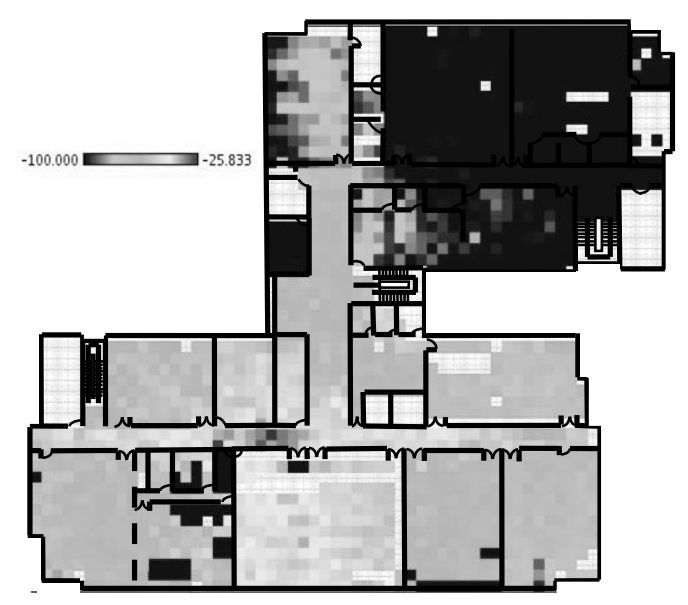

Gambar 6. Visualisasi peta fingerprint pada AP-2

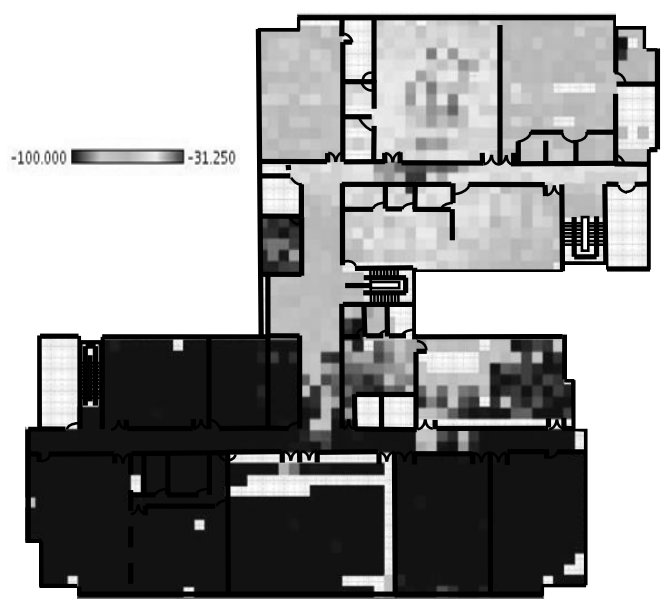

Gambar 7. Visualisasi peta fingerprint pada AP-3

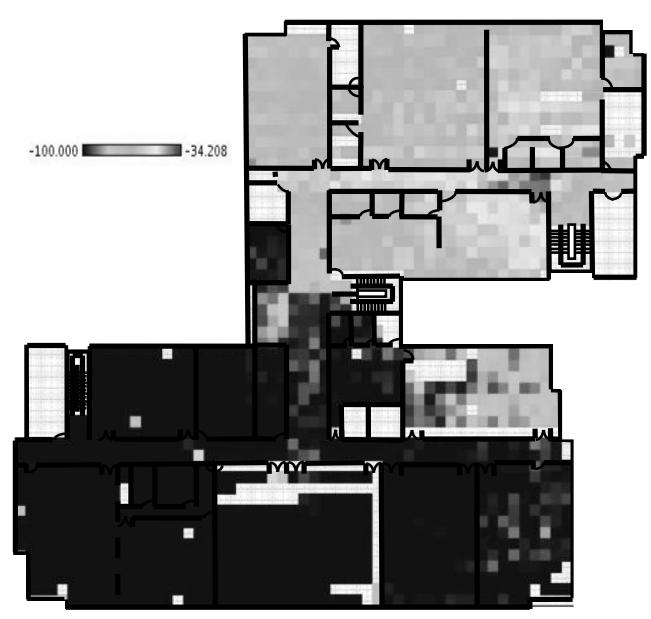

Gambar 8. Visualisasi peta fingerprint pada AP-4

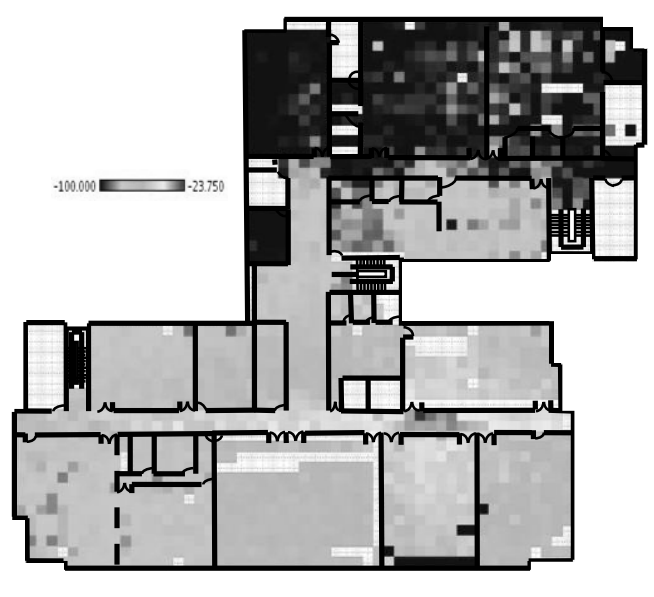

Gambar 9. Visualisasi peta fingerprint pada AP-5

Tahap training dan testing RSS fingerprint (tahap learning) menggunakan software RapidMiner 5.0. Tahap learning menggunakan data fingerprint untuk data training sebesar $80 \%$ yang berjumlah 53120 data dan data testing sebesar $20 \%$ yang berjumlah 12312 data.

Tabel 1. Hasil learning localization lantai 3 pada tahap off-line

\begin{tabular}{lc}
\multicolumn{1}{c}{ Hasil } & Naive Bayes \\
\hline Akurasi (meter) & 6,29 \\
Standar Deviasi error jarak (meter & 8,29 \\
\hline
\end{tabular}

\section{B. Fase Online dan Tahap Post Learning}

Pada fase online, dilakukan pengujian terhadap nilai $R S S$ yang diukur secara real time dengan cara berjalan pada koridor di lantai 3 dan memasuki ruang Lab Jaringan Komputer gedung JTETI UGM. Proses pengukuran dan pola jalan dapat dilihat pada gambar 10 dengan jumlah lokasi target sebesar 328 titik lokasi. 


\section{PENUTUP}

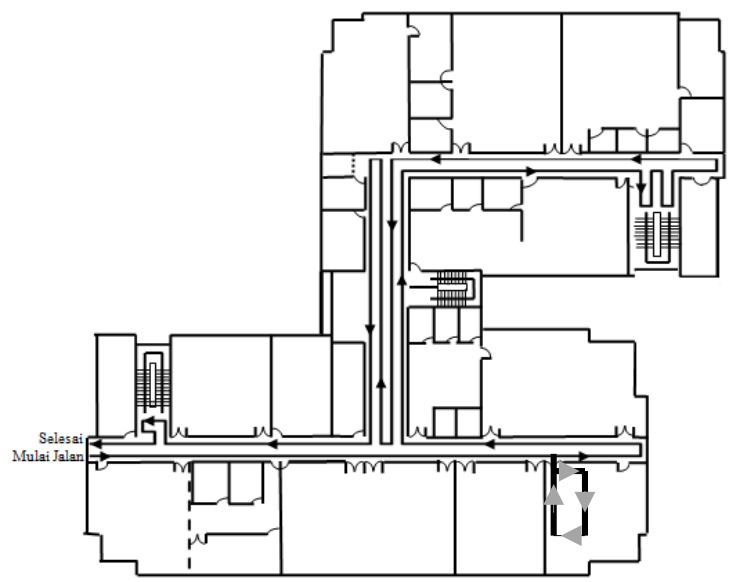

Gambar 10. Pola jalan pengukuran RSS secara real time pada fase online

Tabel 2. Rata-rata error jarak estimasi dan standar deviasi pada localization lantai 3 pada tahap post learning

\begin{tabular}{lc}
\hline \multicolumn{1}{c}{ Keterangan } & Naive Bayes $(\mathbf{m})$ \\
\hline Rata-Rata Error jarak Estimasi & 7,82 \\
Standar Deviasi & 8,50 \\
\hline
\end{tabular}

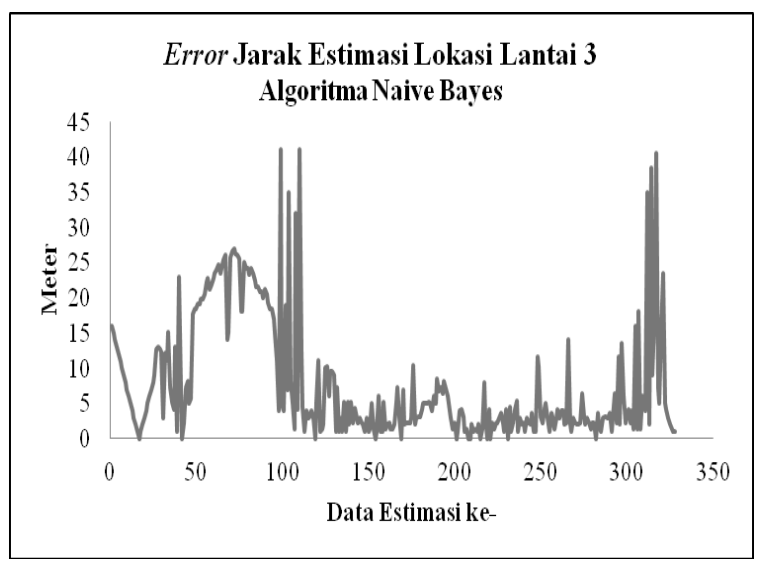

Gambar 11. Error Jarak Estimasi Lokasi Lantai 3 Menggunakan Algoritma Naive Bayes pada tahap post learning

Gambar 12 merupakan trajectory estimasi lokasi pada masing-masing algoritma di lantai 3.

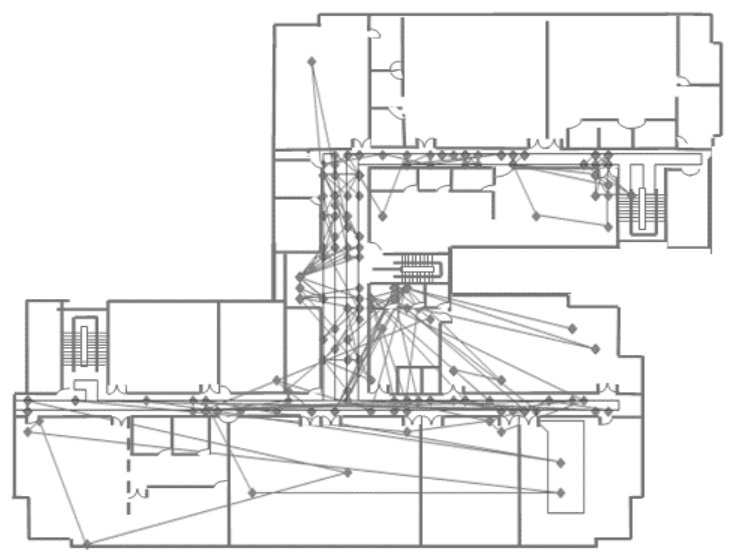

Gambar 12. Trajectory estimasi lokasi target terhadap lokasi sebenarnya dengan algoritma Nä̈ve Bayes.

\section{A. Kesimpulan}

Berdasarkan penelitian yang telah dilakukan dapat diambil kesimpulan sebagai berikut.

1. Pada fase off line nilai rata-rata error jarak estimasi yang diterapkan pada localization untuk seluruh ruangan di lantai 3 gedung JTETI menggunakan algoritma Naive Bayes sebesar 6,29 meter.

2. Pada fase online diperoleh rata-rata error jarak estimasi dengan menggunakan algoritma Naive Bayes sebesar 7,82 meter

\section{B. Saran}

Berdasarkan hasil penelitian yang telah dilakukan, ada beberapa saran dalam proses pengembangan penelitian untuk meningkatkan akurasi estimasi posisi, antara lain.

1. Pembuatan peta RSS fingerprint dapat dikembangkan dengan menambahkan arah posisi pengukuran yaitu selatan, barat, dan timur.

2. Pembuatan peta RSS fingerprint dapat juga dikembangkan dengan memperkecil dimensi grid menjadi 0,5 meter.

3. Localization dapat dikembangkan dengan mempertimbangkan efek multipath dan propagasi gelombang.

4. Dapat dikembangkan penggunaan metode Principal Component Analysis (PCA) untuk memilih access point yang paling berpengaruh terhadap estimasi lokasi.

5. Localization dapat menggunakan algoritma lain untuk mengetahui nilai error yang lebih kecil.

Dimasa datang akan dilakukan localization pada seluruh lantai 3 gedung JTETI UGM dengan menggunakan algoritma penentuan posis yang lain untuk mendapatkan nilai akurasi yang lebih besar dan rata-rata kesalahan jarak/error distance yang lebih kecil.

\section{DAFTAR PUSTAKA}

[1] Ahmed, U., Gavrilov, A., Lee, S., and Lee, Y. K., 2007, " A Rapid Development Approach For Signal Strength Based Location System", International Conference On Intellegent Pervasive Computing, 07695-3006-0/07 IEEE, DOI 10.1109/IPC.2007.62.

[2] Bensky, A., 2008, "Wireless Positioning: Technologies and Application, ser. GNSS technology and application series", Artech House Publishers.

[3] Chen, L. H., Jin, M. H., and Wu, E. H., 2010, "A Novel RSS-Based Indoor Positioning Algoritm Using Mobility Prediction", IEEE, International Conference on Parallel Processing Workshops.

[4] Derr, K., Manic, and M., 2008, "Wireless Indoor Location Estimation Based on Neural Network RSS Signature Recognition (LENSR), IEEE Conference on Industrial Electronics and Applications. 
[5] Ethem, A., 2010, "Introduction To Machine learning", Second Edition, The MIT Press, Cambridge, Massachussetts, London, England.

[6] Fang, S. H., Lin, T. N., and Lee., K. C., 2008, “A novel algorithm for multipath Fingerprinting in indoor WLAN environment", IEEE Transactions On Wireless Communications, Vol. 7, No. 9, pp. 35793588.

[7] Garcia, M., Martinez, C., Tomas, J., and Lloret, J., 2007, "Wireless Sensors self-location in an Indoor WLAN environment", International Conference on Sensor Technologies and Applications, 0-7695-29887/07 IEEE, DOI 10.1109/SENSORCO MM.2007.63.

[8] Kaemarungsi, K., 2005, "Design Of Indoor Positioning Systems, Based On Location Fingerprinting Technique", Disertasi.

[9] Kaemarungsi, K., 2005, "Efficient Design of Indoor Positioning Systems Based on Location Fingerprint, IEEE.

[10] Liu, H., Darabi, H., Banerjee, P., and Liu, J., 2007, "Survey of Wireless Indoor Positioning Techniques and Systems", IEEE Transactions On Systems, Man, And Cybernetics-Part C: Applications And Reviews, Vol. 37, No. 6, November.
[11] Pan, S. J., Zeng, V. W., Yang, Q., and Hu, D. H., 2008, "Transfer Learning for WiFi-based Indoor Localization", Association for the Advancement of Artificial Intelligence.

[12] Tran, D. A., 2009, chapter in book "Machine Learning Based Localization" (eds: Guoqiang mao and Baris Fidan, IGI Global).

[13] Widyawan, 2009, “Learning Data Fusion for Indoor Localization", Department of Electronic Engineering Cork Institute of Technology, A thesis submitted for the degree of Doctor of Philosophy.

[14] Yeung, W. M. and Joseph, K. Ng. 2007, "Wireless Lan Positioning Based On Received Signal Strength From Mobile Device And Access Points", 13th IEEE International Conference on Embedded and RealTime Computing Systems and Applications (RTCSA 2007), 0-7695-2975-5/07.

[15] Zhou, J., Young, W. M., and Kee-Yin Ng, J., 2008, "Enhancing Indoor Positioning Accuracy By Utilizing Signals From Both The Mobile Phone Network And The Wireless Local Area Network", 22nd International Conference on Advanced Information Networking and Applications, IEEE. 